\title{
A RESISTÊNCIA AO DISCURSO NACIONALISTA HEGEMÔNICO NA DRAMATURGIA DE SEAN O’CASEY
}

\author{
RESISTANCE TO HEGEMONIC NATIONALIST DISCOURSE IN SEAN \\ O'CASEY'S DRAMATURGY
}

\author{
Raimundo Expedito dos Santos Sousa ${ }^{1}$
}

Resumo: A fim de provar a virilidade dos homens irlandeses, subestimados pelo império britânico, o nacionalismo anticolonial implicou suspensão provisória do código de masculinidade civil em favor do código de masculinidade cívica, na qual o romance heteroerótico deveria ser proscrito em benefício da nação. Sean O'Casey, divergente desse ideário propalado pelo teatro nacionalista, enfoca em suas obras o descaso pela mulher-carne em favor da mulher-símbolo. Mediante exame da peça The Plough and the Stars, este trabalho verifica como o dramaturgo desconstrói o mito sacrificial na medida em que denuncia a patologização do nacionalismo como histeria coletiva decorrente da interdição a Eros.

Palavras-chave: Irlanda; Teatro; Nação; Sean O’Casey; Resistência.

Abstract: In order to prove the virility of Irish men, underestimated by the British Empire, anticolonial nationalism entailed a temporary suspension of the civil masculinity code in favor of the civic masculinity code, in which the heteroerotic romance was to be outlawed for the benefit of the nation. Sean O'Casey, divergent from this ideology promoted by the nationalist theatre, focuses on his works the neglect of the woman-flesh in favor of the woman-symbol. By examining the play The Plow and the Stars, this paper examines how the playwright deconstructs the sacrificial myth in that he denounces the pathologization of nationalism as collective hysteria resulting from the interdiction of Eros.

Keywords: Ireland; Theatre; Nation; Sean O’Casey; Resistance. .

\footnotetext{
1 Professor de Língua Portuguesa na Faculdade do Centro Educacional Mineiro (FACEM BH). Doutor em Teoria da Literatura e Literatura Comparada na Universidade Federal de Minas Gerais (UFMG). E-mail: raimundo_sousa@terra. com.br
} 


\section{INTRODUÇÃO}

Em trabalho seminal, Anderson (1983) sublinha a instrumentalidade da imprensa na consolidação do nacionalismo moderno por facultar, mediante produção e circulação de textos em larga escala, a difusão do sentimento de integralidade entre concidadãos que se imaginam pertencentes a uma comunidade una e indivisa. Embora passe ao largo da universalização de valores dominantes, ao não problematizar, como aponta Chatterjee (1993), qual ideia de nação é imaginada a expensas de qual e quem a imagina em detrimento de quem, sua definição supera o reducionismo das precedentes ao caracterizar a nação, para além de entidade geopolítica, como um construto ficcional que, todavia, não se dá ex nihilo, mas mediante apropriação de repertórios culturais disponíveis. Se esse exercício imaginativo dependeu de gêneros textuais como o jornal impresso (ANDERSON, 1983) e o romance (SOMMER, 1991), os irlandeses, majoritariamente iletrados e despossuídos de tradição romanesca, dependeram de antigas práticas orais como a canção e a dramatização para se imaginarem, de maneira que a nação seria mais ouvida e contemplada do que propriamente lida. Uma vez que a nação, longe de imaginada de forma definitiva, depende de contínua reinvenção, o teatro a significaria iterativamente, de modo que a produção dramática, para além de entretenimento, assumiria a missão pedagógica de disseminar uma "consciência nacional". Dado que, paralelamente à luta anticolonial irlandesa, conflitos intestinos levavam ao enfrentamento entre facções políticas antagônicas que pleiteavam a primazia de determinar como e por quem a nação seria imaginada, "o drama (produção de textos para encenação) e o teatro (formação dos meios de produção e condições de recepção do drama) seriam instrumentais na definição e sustentação de uma consciência nacional" (MURRAY, 1997, p. 3). Como "mídia" de maior envergadura do que o texto impresso, o teatro era ovacionado como instrumental no processo de descolonização. Tal seria o contributo do drama no processo de descolonização do imaginário que a Irlanda, primeira colônia inglesa a obter independência, inspiraria outras a também se valerem do drama em seus projetos de emancipação, tais como a Austrália, onde Louis Esson, à semelhança dos irlandeses, criou um teatro nacional; a Nigéria, onde escritores como Wole Soyinka se interessaram, a partir dos irlandeses, pela relação entre teatro e nacionalismo; e o Caribe, onde Derek Walcott se inspirou no dramaturgo John Synge (INNES, 2007).

O teatro conquistou hegemonia cultural ao propalar a unidade na (a)d(i)versidade ou seja, a suplantação da antiga querela entre separatistas e unionistas e a então recente cisão do Partido Nacionalista após a queda de Charles Parnell - e negar qualquer filiação política, sob promessa de manter-se "fora de todas as questões políticas que nos dividem" (GREGORY, 1913, p. 9). Ao se comprometerem, ainda, em mostrar a um público "cansado de representações distorcidas" que a Irlanda "não é o templo da bufonaria e do sentimento gratuito, como tem sido representada, mas o templo de um idealismo ancestral" (GREGORY, 1913, p. 9), os idealizadores do movimento teatral prometiam desconstruir estereótipos coloniais para um público ávido por exibições espe(ta)culares das virtudes nativas. Tal expectativa se fundava numa concepção teatral emergente ainda na Antiguidade, pois desde a Poética de Aristóteles se identifica o teatro, notadamente a tragédia, à noção de sacrifício por tematizar a fatalidade do destino em face do qual o sofrimento e imolação do herói pur- 
gam a audiência mediante identificação catártica cujo efeito terapêutico Freud (1969) comparou ao experimentado pela criança em brincadeiras de faz-de-conta. Do mesmo modo que esta reage à angústia decorrente de suas restrições e fragilidades imaginando-se capaz de lograr grandes feitos, o espectador, ao identificar-se com o herói, sente-se ele próprio um grande homem e, em fantasia, transporta-se de sua condição anódina para uma dimensão sobre-humana. A expectativa de cumprimento dessa função terapêutica pelo teatro seria determinante no circuito de produção e recepção das peças, pois a estética sacrificial da tragédia se orquestrou de tal sorte com a ética sacrificial do nacionalismo que a valoração do teatro teria como quesito primeiro a satisfação de uma plateia ávida por kathársis.

Todavia, dramaturgos houve que destoaram dos protocolos de representação estabelecidos na medida em que expuseram críticas ao próprio nacionalismo a que em tese se alinhavam. Na peça John Bull's Other Island, de Bernard Shaw, um irlandês cosmopolita, cujo olhar distanciado favorece sua percepção crítica acerca do país, credita a estagnação deste ao efeito patológico do nacionalismo sobre a psiquê coletiva:

A imaginação de um irlandês [...] faz com que ele não consiga encarar a realidade, nem lidar com ela, nem contê-la, nem conquistá-la [...]. Ele não consegue ser inteligentemente político [...]. Se você quiser interessá-lo [...] você precisa chamar de Kathleen ni Hoolihan a desafortunada ilha e fingir que ela é uma velhinha. Isso economiza pensamento. Isso economiza trabalho. Isso salva tudo, exceto a imaginação [...]; e imaginação é uma tortura que você não pode suportar sem uísque (SHAW, 1907, p. 19).

Ao desmascarar o escapismo bovarista dos irlandeses em imaginar sua ilha sob um significante feminino como compensação psíquica para a castração política, o personagem ecoa o próprio dramaturgo, que, certo do caráter alienante do projeto de nação a que o movimento teatral se vinculava e contrário aos quantos ovacionaram Cathleen ni Houlihan, de Yeats, alertou que a peça "podia levar um homem a cometer uma sandice" (apud CULLINGFORD, 1990, p. 12). No contrafluxo do entusiasmo global pelo nacionalismo, Shaw encabeçava uma contraideologia que o identificava como patologia similar à que Marx e Freud identificaram na religião. Todavia, não foi Shaw, mas seu discípulo Sean O'Casey - que afirmava ter conhecido a "verdadeira Irlanda” ao ler sua peça (apud O’RIORDAN, 1976, p. 177) - que criticou mais duramente a alienação nacionalista ao revisitar, em um revisionismo avant la lettre, eventos históricos como o Levante da Páscoa (The Plough and the Stars, 1926), a Guerra dos Black-and-Tans (The Shadow of a Gunman, 1923) e a Guerra Civil (Juno and the Paycock, 1925).

Quando o prognóstico de que uma nação edênica sucederia à guerra se cumpriu ao revés e aqueles que haviam lutado juntos pela descolonização agora se digladiavam em batalhas internas pela hegemonia política local, O’Casey, que transitara pelas principais confrarias nacionalistas e partilhara do sonho de nação, insurgia-se contra a ortodoxia do nacionalismo, que naturalizava disjunções de gênero e distraía o operariado de sua agenda. O escritor não concebia a clivagem entre descolonização e emancipação de classe e gênero 
porque ciente de que a autonomização política só teria sentido se desatrelada dos interesses de grupos dominantes; caso contrário, sem embargo da forma de governo, a propriedade privada dos meios sociais de produção e a supremacia de valores androcêntricos perpetuariam relações de dominação, engendrando uma colonização interna deslocada do império para as elites locais. Numa encruzilhada entre ideologias que mal se orquestravam, O'Casey optou por aquelas solidárias com os subalternos, com os quais se identificava, de maneira que sua empatia com o feminismo o atentou para a assimetria de gênero, distanciando-o do nacionalismo androcêntrico, e sua adesão ao socialismo o afastou do cristianismo, por pressupor imanência, não transcendência, e do nacionalismo, por ter caráter anti-hegemônico e transnacional. Dentre suas peças históricas, The Plough and the Stars, a que me deterei neste artigo, interessa não apenas por ser a mais completa e tematizar o Levante, que marca o "nascimento" da nação, mas também por sintetizar suas principais críticas às instituições opressivas e, ao fazê-lo, expor mais claramente sua patologização do nacionalismo.

\section{DUBLIN, CIDADE HIST(Ó)(É)RICA}

Vítima de inúmeras tentativas de censura, The Plough and the Stars protagonizou o terceiro grande escândalo na história do Abbey Theatre, quando manifestantes, sobretudo mulheres, tumultuaram uma de suas primeiras apresentações com gritos, vaias, cânticos republicanos, invasões ao palco, explosões de bombas e ataques físicos ao elenco. Enojado pela forma como a peça representava seu país, o então presidente da Gaelic League, P. T. McGinley, deixou o teatro antes mesmo do Segundo Ato, dizendo-se acometido de um "acesso de náusea" (apud KRAUSE, 1960, p. 129), e perdeu o clímax do espetáculo, relatado por uma "testemunha ocular" no The Observer do domingo seguinte. Segundo a testemunha, a peça foi interrompida por uma "ilógica" manifestação republicana liderada por Hanna Sheehy-Skeffington, que discursou contra cenas ofensivas à memória dos mártires e à moral do país, enquanto umas vinte "moças encolerizadas", acompanhadas de alguns rapazes, precipitaram rumo ao palco e fizeram tudo quanto podiam para descer as cortinas abaixo, gangorrando-se nelas, além de chutarem lâmpadas e agredirem o elenco. Ainda insatisfeitas, algumas "moças bravas" treparam no palco e se balançaram até que este desabou, e em seguida rasgaram cortinas e destruíram mais lâmpadas (GWYNN, 1926). O espírito beligerante que animava a peça tomava a audiência, engajada numa batalha em que saraivadas de sapatos cruzavam o ar:

Os jornais diziam que a Srta. Delany havia sido atingida no rosto por um rapaz. Mas [...] ele [...] disse que havia jogado algo em Seaghan Barlow e acidentalmente bateu na senhorita Craig. Miss Richards diz que ela mesma jogou um sapato em um dos intrusos e errou o alvo e um deles o pegou e o jogou em Yeats, mas também errou o alvo (GREGORY, 1947, p. 97).

Em meio a essa comédia de erros, um ator, que durante os ensaios tivera uma crise nervosa e atirara ao chão seu script, em novo "ataque de neurose" tentava discursar contra 
O'Casey (FALLON, 1965, p. 91) e os colegas, em defesa do escritor, fecharam-lhe as cortinas na cara (RICHARDS, 1976). Em patente contradição, a peça solidária com as mulheres foi reprovada exatamente por elas, pois o feminismo das manifestantes era subordinado ao nacionalismo, cuja concepção de feminilidade, atrelada à resignação marial, impedia-lhes de se identificarem com personagens como Nora Clitheroe, que tenta impedir o marido de se entregar pela Irlanda. Como argumentou a viúva de Francis Sheehy-Skeffington, "[a]s mulheres da Semana da Páscoa, tal como as conhecemos, são tipificadas, ao contrário, na mãe de Padraic Pearse, aquela mulher valente que deu ambos os filhos pela liberdade" (apud PORTER, 1976, p. 111).

Ao enaltecer O'Casey por ter entretido as manifestantes, transformando "senhoras frenéticas" em "belos seres femininos", a atriz Sheilla Richards (1976, p. 176), iterando o mito da incompatibilidade entre feminilidade e ativismo, sugeria que velhas irritadiças finalmente se feminizam quando libertas do furor político. A mesma percepção era corroborada por O'Casey (1949) ao rememorar as vozes "altissonantes, histéricas e distorcidas" das manifestantes (p. 238), identificando o protesto como uma histeria coletiva; por Joseph Holloway (1967), ao relatar que "[d]o início ao fim tudo não passou de uma algazarra de mulher” (p. 11); e por Lady Gregory, que, recusando-se a convidá-las para um debate público, tal como na ocasião da revolta contra sThe Playboy of the Western World, justificou: "Na época de Playboy nossos oponentes eram homens. Eles tinham um objetivo definido [...]. Essas desordeiras eram, em sua maioria, mulheres que [...] criaram o hábito da [...] baderna” (GREGORY, 1947, p. 96). A caracterização da manifestação como animada menos por uma agenda política consistente do que por afeição à algazarra se devia, em larga medida, à sua liderança por mulheres - em sua maioria participantes no Levante e na Guerra Civil - cujo agenciamento desestabilizava um nacionalismo comprometido com a remasculinização racial, por sua vez dependente da mulher-como-vítima para elevação do homem-como-herói. O fato de nenhum dos manifestantes ter sido preso sugere a condescendências das autoridades que tomaram o episódio como uma performance, num nacionalismo em que as balizas entre factualidade e ficção se diluíam de tal forma que o Levante teve, segundo testemunhou Michael Collins, "ares de uma tragédia grega" (apud COOGAN, 2002, p. 54). De fato, a teatralidade transcendia a encenação da peça e tomava a plateia, envolvida numa sucessão de performances dramatizadas, bem como a tribuna, onde Yeats, em uma de suas aparições estilizadas, admoestou a audiência.

Em geral ufanistas, os registros históricos e literários sobre o Levante desconsideravam que os irlandeses se haviam esquecido de sua oposição inicial ao evento e agora o viam como um louvável sacrifício e seus líderes como mártires, evocando uma tradição sacrificial que os vinculava a heróis de sublevações precedentes. Mas O’Casey (1949) captou com perspicácia que essa tradição era forjada no ato mesmo de sua menção, e, bem antes de Hobsbawm e Ranger, identificou ali uma "tradição inventada" (p. 348), que se fundava numa unidade nacional subtrativa e numa memória cultural amnésica. Ao conferir relevo exatamente aos párias sociais, o escritor, que vivia junto a proletários, alcoólatras e prostitutas, narrou o Levante "a partir de baixo", antecipando na literatura o que no final daquela década seria propalado pela École des Annales, difusora de novo prisma sobre o fazer historiográfico. 
$\mathrm{Na}$ controversa cena do botequim, na qual os párias sociais vez por outra pausam sua algazarra para enaltecer os dizeres da "Figura na Janela", caricatura de Pádraic Pearse, a identificação inconsistente dos subalternos, que, em gestos e atitudes grotescos, contradizem o discurso idealista ao tempo em que professam adesão à causa, sinaliza sua impossibilidade de identificação com uma ideologia alheia a seus anseios. De fato, o botequim figura como palco para a performance de tipos parodiais que compõem uma cenografia profana contrastante com a solenidade do Levante, formatado conforme interesses de grupos hegemônicos e, portanto, incapaz de cooptar as massas. Já que, respectivamente, a temperança e a pureza eram virtudes cardinais para homens e mulheres, o beberrão e a prostituta, embora necessários como limites da masculinidade e da feminilidade sadias, causavam desconforto ao exprimirem idealismos patrióticos. Excluídos do direito ao sacrifício, os beberrões testemunham, como arestas da masculinidade hegemônica, a contradição de um contexto beligerante que enaltecia a masculinidade cívica, mas não franqueava a todos os homens o direito de cumpri-la. Os civis Peter e Fluther imitam essa masculinidade encarnada na figura do rebelde e, inflamados pela retórica beligerante, correm antes para o botequim do que para as trincheiras, confessando-se dispostos a matar ou morrer pela pátria e encontrando na bebedeira a canalização de seus investimentos agressivos. Uniformizado ridiculamente e ostentando uma enorme espada, desproporcional ao seu tamanho, Peter assume uma pose hipermasculina cujo efeito paródico assinala a impossibilidade dos subalternos desempenharem, senão caricaturalmente, uma performance de gênero incompatível com suas condições reais de existência, de maneira que qualquer tentativa de pertencimento reforça exatamente sua exclusão.

A figura da prostituta Rosie Redmond era ainda mais intolerável por afrontar não somente a feminilidade nativa, mas também a masculinidade dependente desta como complemento. Daí uma das manifestantes, devotada ao papel de zeladora da memória cultural, ter informado a O'Casey (1949) que “em toda a Irlanda, de uma ponta a outra, não existe uma prostituta sequer" (p. 240). Seu exercício de esquecimento se coadunava com um projeto de nação cuja noção de respeitabilidade dependia da obliteração de um fenômeno social tão comum que toda noite a atriz Ria Mooney, ao dirigir-se ao Abbey caracterizada como meretriz, era agredida por prostitutas que atendiam nas imediações do teatro e a tomavam como concorrente (GRENE, 2005).

Enquanto prostituta, Rosie é prejudicada pela debandada de sua clientela e excluída dos direitos de cidadania advindos com o Estado Livre. Seu pragmático lamento quanto à escassez de clientes consiste num réquiem pela masculinidade civil, cuja natureza menos sublimatória lhe garantia a clientela:

Não há muita atenção para uma linda anágua numa noite como esta ... Eles estão todos com um humor sagrado. O olhar solene de todos eles enquanto eles marcham para o encontro... Você pensaria que eles eram a gloriosa companhia dos santos e o nobre exército de mártires passando pelas ruas do paraíso. Eles estão todos pensando em coisas mais elevadas do que a meia-calça de uma garota (O'CASEY, 1964², p. 161-162).

2 Doravante o texto será referenciado pela abreviação PS seguida do número da página. 
Já que tanto a prostituta quanto o proselitista dependem da massa de homens e prometem como recompensa, respectivamente, uma petit mort e uma morte grandiosa, o primado da masculinidade cívica e sua contraface, a interdição ao heteroerotismo, impõem-se na medida em que, nessa competição pela atenção masculina, a mulher é preterida por homens seduzidos por um dos seus. Assim, numa formação discursiva que atrela hombridade e beligerância, os rebeldes, alienados pela promessa de glória, professam lealdade à Irlanda, subestimando suas mães e esposas:

Tenente Langon: O tempo está podre de maduro para a revolução.

Clitheroe: Você tem uma mãe, Langon.

Capitão Brennan: Você tem uma esposa, Clitheroe.

Clitheroe: A Irlanda é maior do que uma esposa (PS, 178).

Inscrita no mundo dos negócios a um só tempo como agente comercial e commodity, a prostituta, seguindo as leis do mercado, vale-se de estratégias diversas para conquistar clientes. Seu assédio ao pudico The Covey, que confunde suas intenções e a chama de "camarada", em antierótica linguagem corporativa, inverte os protocolos de gênero que designam ao homem o papel proativo no flerte amoroso e à mulher o papel reativo. Inconformada ao ver o rapaz "pensando em qualquer coisa, ou admirando qualquer coisa, menos as meias de seda transparentes mostrando as [...] pernas de uma mocinha" (PS, 165), Rosie tenta convencê-lo a um programa "com sua noivinha querida" (PS, 166), jogando com estereótipos duais como a mulher "vadia" e a moça "de família". Além de dissociar o sexo da reprodução, do casamento e do amor, a prostituta, como atriz itinerante, carnavaliza identidades, assumindo performaticamente papéis diversos, já que, liberada das injunções da procriação, ocupa-se com a criação. Seu empenho evidencia o paradoxo do principal estereótipo atribuído à prostituta, pois, como observa Paz (1950), a imagem da mulher à-toa, vagabunda ou vadia é paradoxalmente acompanhada pela noção de atividade: ao contrário da dona-de-casa encerrada no âmbito doméstico, a prostituta trafega por fronteiras espaciais e simbólicas, contradizendo a idealização da mulher como sexual e economicamente inativa. Ao transitar por espaços que não o da domesticidade, figurando como contraface feminina do flâneur, a "mulher da rua" epitomiza o anonimato do espaço urbano e despojo da ordem capitalista e, precisamente por vincular a venda ao apelo sexual, torna-se o emblema perfeito do fetichismo da mercadoria.

Tomada pelos opositores como elaboração de uma mente pornográfica, a figura da prostituta sedenta por sexo encarna o desejo pela vida, simbolizado por Eros, de forma que assentir ao assédio da prostituta significa, no contexto da peça, apostar na vida. Assim, enquanto os militares evocam a morte, o civil Fluther Good acompanha Rosie na celebração do élan vital e, em vez de alimentar Cathleen ni Houlihan com seu sangue, sacia, com sêmen, a candente Rosie, cuja canção vincula hombridade e potência sexual pela comparação entre um amante impotente, que "não podia fazer nada por mim", trocado por outro tão viril que "[n]ós nos abraçamos e beijamos com devoção, até que a noite da manhã tinha fugido; / Lá, para nossa alegria, um garoto saltitante na cama estava a dançar!” (PS, 179). 
Porém, o ponto nevrálgico da transgressão de O'Casey em sua versão do Levante da Páscoa consiste na formatação sacrificial. Em um nacionalismo no qual o teatro deveria propalar o sacrifício, mas não exibir sua realização - já que o cadáver, segundo (KISTEVA, 1982), constitui o extremo da abjeção enquanto lembrança da finitude humana - e no qual a primazia da remasculinização racial negava à mulher o direito ao sacrifício, The Plough rompe dois paradigmas ao exibir a cena sacrificial, protagonizada exatamente por uma mulher. Ao salvar Nora, Bessie é baleada por um franco-atirador e, embebida em sangue, agoniza: "Deus misericordioso, estou baleada [...] A vida está vazando de mim! (A Nora) Eu estou assim [...] por causa de você, sua puta, de você!” (PS, 215). Ao heroicizar uma figura abjeta que transita entre o pietismo religioso e o chulo maldizer, O'Casey não só relativiza a noção de heroísmo, como também denuncia a falácia da romantização da violência, pois, na contramão da martiriolatria que idealizava o rifle como instrumento refalicizador, a dizimação de civis evidencia sua destrutibilidade.

Enquanto o protesto, um evento histérico, torna-se histórico pela repercução adquirida, a peça representa um evento histórico, o Levante, como histérico. Com a voga científica no século XIX e seu espraiamento pelo tecido social, a aplicação de clichês médicos para significação de fenômenos extrínsecos ao domínio da medicina era tal que o léxico psiquiátrico oferecia aos oponentes do nacionalismo ortodoxo um repertório discursivo para denunciar a natureza patológica de um nacionalismo que, a exemplo da religião, que Freud (1974[1907]) qualificou como a neurose obsessiva universal, torna-se alienante quando fomentado pelo fanatismo. O adjetivo "histérico(a)", que havia-se popularizado como qualificativo para toda forma de desrazão, sintetizava a gama de "insanidades" imputadas aos nacionalistas conservadores, permitindo a James Joyce (1959) referir-se ao Gaelic Revival como um "nacionalismo histérico" (p. 186) e a W. B. Yeats (1961) descrever os nacionalistas puritanos como "uma histérica que faz acusações desmedidas e crê no impossível" (p. 314). Mas entre os literatos foi O’Casey quem mais se apropriou do léxico psiquiátrico para caracterizar o Levante de 1916 como um evento não só histórico, mas também histérico. Ainda que não observe de todo as convenções naturalistas, The Plough and the Stars sugere um atrelamento determinista entre a formatação do self e as condições do meio, sobretudo a causalidade entre a mutilação dos dublinenses sob o jugo de instituições opressivas e seu consequente acometimento por transtornos psicossexuais diversos. Na peça informada por princípios do melodrama - estética que visa a reproduzir na plateia o pathos dos personagens mediante representações espetaculosas -, homens e mulheres não gratificados sexualmente e confinados no cenário claustrofóbico das barricadas ou do cortiço exibem comportamentos irritadiços, eufóricos ou melancólicos, bem como somatizações hipocondríacas e repetições obsessivo-compulsivas. Em contraposição ao herocultismo prevalecente em outros autores à época, em O'Casey os rebeldes são caracterizados como frágeis, medrosos e governados pela "excitação emocional" (PS, 177). Acometidos por "espasmos de agonia", "estado de colapso" e "plácida nervosidade" (PS, 193), contradizem na expressão somática do sofrimento a quimera do sacrifício como jouissance. Entre os civis, Peter, caracterizado pela expressão de "angústia" e "rebeldia" (PS, 136), é xingado de "lunático" (PS, p. 146) e descrito como "[h]istérico" (PS, 152); a Sra. Gogan, descrita como "irrequieta”, "nervosa” e "terrivelmente faladeira" (PS, 137), ora sai "dando risadas histericamente" (PS, 145), ora é 
assaltada por uma "violenta tempestade de furor histérico" (PS, 170). Coadunada com uma estética melodramática que hiperboliza as emoções, a caracterização genérica dos personagens como histéricos não obedece rigorosamente às especificidades clínicas da doença, pois consiste, antes, numa forma de sublinhar a noção de descontrole. Escrita em um contexto no qual o termo "histeria" designava, lato sensu, uma variedade de "desordens" emocionais e no qual a medicina caracterizava a histeria, stricto sensu, como uma sucessão de performances e sublinhava em sua etiologia a repressão sexual, a histerização designa, na peça em estudo, menos um quadro clínico individual do que os efeitos da ortodoxia nacionalista e religiosa sobre militares e civis.

Exemplo mais inequívoco dessa histerização, Nora clama pelo marido "em histérico protesto" (PS, 184), afirma que o amor por ele a deixou "louca de terror" (PS, 196) e, no ápice de seu colapso nervoso, aparece em cena de camisola, com os cabelos desgrenhados, o rosto empalidecido, as mãos agitadas e os olhos exibindo "a luz da incipiente insanidade" $(P S, 204)$. Tal como uma "típica" histérica, a personagem fantasia soluções imaginárias para suas frustrações, deixando entrever o elo entre loucura e pulsões sexuais não gratificadas ao pedir ao marido, em devaneio projetivo, que "[n]ão me beije assim; você me tira o fôlego, Jack” (PS, 205). Sua caracterização como histérica é crucial na composição da personagem porque confere visualidade a seu sofrimento e relevo às suas denúncias, já que, segundo Copjec (2004), a histérica, insurgente contra a inautenticidade que observa no mundo, "não é preenchida com as autoacusações pelas quais aqueles que recaem sob a influência do superego são sobrecarregados, mas, pelo contrário, torna-se, por assim dizer, superego para o mundo" (p. 126).

Embora, em outras peças do projeto nacional irlandês, nenhum dos preteridos aceitasse facilmente a perda de seu amor pela causa nacional, Nora, a mais arrojada, tem sua pena triplicada ao perder o marido, o filho e a sanidade. Por meio da personagem contrária à ilusão de que as mulheres despacham, de bom grado, seus homens para a guerra, O'Casey antecipa Freud, que, em ensaio de quatro anos mais tarde, identificaria a mulher como afeita à família e à sexualidade e o homem ao empreendimento civilizatório. Para o psicanalista, o homem, porque mais apto às sublimações instintivas, desloca suas pulsões heteroeróticas para finalidades culturais de tal maneira que "[s]ua constante associação com outros homens e a dependência de seus relacionamentos com eles o alienam [...] de seus deveres de marido e de pai", enquanto a mulher, negligenciada em prol dos imperativos da civilização, "adota uma atitude hostil para com ela" (FREUD, 1996, p. 109). À diferença de Freud, para quem a sublimação - termo emprestado das Ciências Naturais (ali referente à transmutação da matéria do estado sólido para o gasoso) para dar conta da "purificação" do desejo pela simbolização - convertia as pulsões rivais em aliadas do processo civilizador, O’Casey denuncia a falácia da sublimação ao sugerir que onde o amor é suprimido o ódio toma seu lugar. Contudo, essa mesma diferença os reaproxima na medida em que o dramaturgo exprime uma convicção sentimental e reducionista de que a esperança restante à humanidade reside na compaixão das mulheres, já que os homens, fanáticos pelo nacionalismo, passam ao largo de virtudes humanas fundamentais. Nessa perspectiva binária, sua reação ao nacionalismo ginófobo se dá mediante um extremismo inversamente proporcional, iden- 
tificando na mulher um apego a valores afetivos a que os homens são pouco suscetíveis e vinculando-a a uma vida instintual regida por impulsos da natureza.

Enquanto ridiculariza a masculinidade hegemônica, o escritor, descrente com o ideal de civilização, hiperdimensiona o atrelamento da mulher à natureza instintiva. $\mathrm{O}$ risco dessa radicalidade que identifica os homens como demasiadamente narcisistas e as mulheres como devotadas ao amor romântico consiste em enredar estas últimas na dependência emocional e na crença de que somente se realizarão como mulheres sendo esposas e mães. Assim, a solidariedade de O'Casey em relação às mulheres recai em patriarcalismo ao identificá-las como dominadas pelo amor. Portanto, embora seu mérito dramático fosse a caracterização, O’Casey, ao se valer do melodrama, constrói personagens monopáticos, carentes de profundidade, pois os homens são movidos pelo ódio e as mulheres pelo amor.

Apesar de audaciosa, Nora se aproxima do paradigma de feminilidade vitoriana pelo devotamento aos cuidados domésticos ao ponto de, em estado de alucinação, imaginar-se preparando o jantar para o marido ou cuidando da criança. Por meio do melodrama, gênero (genre) no qual o estereótipo de gênero (gender) é particularmente visível, O’Casey caracteriza a dona de casa como enlouquecida para enfatizar o impacto da guerra no seio familiar. A instalação da fechadura, já no início da peça, simboliza um esforço pequeno-burguês de lacrar o santuário doméstico, preservando-se a intimidade pela separação entre a casa e a rua - contraponto que, todavia, não problematiza que a célula familiar também constitui uma prisão, já que o "privado", inscrito no mesmo campo semântico de privação, não passa de uma réplica miniatural do patriarcado público no qual a família reproduz hierarquias subjacentes à unidade nacional a partir da estruturação de micropoder que a caracteriza como microcosmo da organização societária. Para diferenciar valores masculinos e femininos, com predileção pelos últimos, O’Casey cinde os espaços público (domínio masculino da política) e privado (domínio feminino do afeto), concebendo a política como deformação de valores humanos, mas não observa que tanto a atuação dos vizinhos como censores sociais quanto os efeitos da institucionalização da violência demonstram que esse culto à domesticidade é ilusório devido à inevitabilidade da interpenetração entre as esferas.

Enquanto, para alguns críticos, certo constrangimento na elaboração de cenas eróticas obriga O'Casey a se valer de estratégias narrativas como circunlóquios e interrupções (cf. KILROY, 1971; WATSON, 1994), a meu ver o suposto constrangimento consiste, antes, numa denúncia de como a ética sacrificial impõe obstáculos à realização amorosa. Na peça em estudo, o entendimento entre Jack e Nora, após longa discussão, pressagia uma noite de amor que, no entanto, malogra quando aquele, finalmente convocado para comandante do Irish Citizen Army, decide regressar à confraria que abandonara porque não promovido ao posto. Tal decisão é atribuída pelos vizinhos, de forma sexista, à inaptidão de Nora em manter a atenção do marido, conforme explica a Sra. Gogan:

Aqueles dois lá costumavam ser como duas pombas-rolas, sempre trocando carícias. Você não podia entrar no cômodo sem sentir, instintivamente, que eles estavam só se beijando e se beijando [...] Mas, creio eu, ele está começando a levar as coisas mais calmamente; o mistério de ter uma mulher não é mais uma mistério... ela se veste para mantê-lo com ela, mas não adianta - depois de um ou dois meses, o encanto de uma mulher desaparece (PS, 138). 
Porque não atento ao primado da homossociabilidade cívica, Kiberd (1995) inclui o desencantamento pela esposa, devido à falta de privacidade no cortiço, entre as motivações do regresso de Jack ao Irish Citizen Army, desconsiderando a guerra como causa vertebral do colapso do casamento. O que Gogan e o crítico literário atribuem ao desencanto por Nora consiste, de fato, numa difícil abdicação do romance em prol do engajamento militar. Jack se ressente da companhia da mulher inobstante a precarização da intimidade e lhe confessa que "queria, por Deus, nunca ter te deixado" (PS, 194), mas, ante o dilema entre demandas inconciliáveis, decide-se pelo compromisso homossocial não apenas por vaidade, mas também por insegurança quanto à sua hombridade. Numa formação discursiva em que esta figurava como um diploma cuja revalidação periódica demandava pôr em risco a própria vida em nome de códigos civis, Jack opta pelo padrão de masculinidade que agrega valor à sua reputação; daí a preocupação em não conspurcar sua honra sendo "desleal com meus camaradas" (PS, 195). Provocado pelo Capitão Brennan, que lhe pergunta se está "com medo" de Nora e o desafia a se desvencilhar da mulher "ou então senta[r] no colo dela de uma vez" (PS, 197), Jack reage lançando-a ao chão com safanões e sacudidelas, concorrendo para a perda do filho, natimorto. Tal reação vincula a subordinação das mulheres às relações de poder entre os homens. Numa cultura na qual masculinidade e dominação se homologam, aqueles em situação vulnerável exprimem virilidade mediante violência contra suas mulheres, de sorte que a fragilidade, egoicamente inadmissível, encontra expressão em sintomas antissociais como a violência doméstica.

Jack, que comprara um cinturão San Browne e, segundo a Sra. Gogan, ficava "sempre vestindo-o e ficando à porta exibindo-o" e "costumava levá-lo para a cama com ele" (PS, 140), veste seu cinturão e põe o rifle no coldre, ratificando no gestual narcísico o fetiche pela indumentária como capital simbólico e extensão do corpo. Essa autoafirmação viril constitui um rito de passagem ilustrativo da transição entre as masculinidades civil e cívica. Dada a impossibilidade de inscrição em dois códigos de masculinidade inconciliáveis (o militar e o civil), o status de chefe de casa, que implica autoridade sobre a esposa e os filhos e proteção da família, era sobrepujado pelo status de comandante do exército, que implica gerência sobre um batalhão de homens e defesa da nação. Afinal, a "carreira" de herói nacional assegurava reconhecimento, independentemente do desempenho: fosse conquistador, o herói seria exaltado por sua conquista; fosse martirizado pelo inimigo, ainda assim seria ovacionado por se sacrificar em benefício de outrem e fortalecer o instinto de resistência nacional.

\section{CONSIDERAÇÕES FINAIS}

A fim de provar a virilidade dos homens nativos, subestimada pelo imperialismo britânico, o projeto de nação irlandês instaurou um código de hipermasculinidade que demandava, em complemento, um código de hiperfeminilidade análogo. Assim, a recursividade da mulher como provação/comprovação da virtude masculina denota uma particularidade do projeto nacional irlandês que o distingue, por exemplo, dos latinoamericanos, em cujas ficções fundacionais o romance atuava como dispositivo harmonizador enquanto "solu- 
ção" para conflitos diversos na medida em que interpelava o leitor a se identificar com o par romântico, de forma que a suplantação dos obstáculos à concretização do romance estimularia um análogo enfrentamento dos percalços à consolidação da nação (SOMMER, 1991). Em contraponto a Sommer, que cogita se no âmbito europeu o romance teria função similar, na politização do gênero e generização da política pelo nacionalismo irlandês nem o romance como gênero literário nem o romance como enlace amoroso foram priorizados. Ao condicionar a revirilização ao engajamento militar, a agenda nacionalista alterou os códigos de masculinidade ao suspender provisoriamente a masculinidade civil, fundada na heterossociabilidade explicitamente vertical e na autocracia doméstica do pater familiae, e ascender a masculinidade cívica, fundada na homossociabilidade aparentemente horizontal e na democracia pública dos brothers-in-arms. Assim, o homem deveria renunciar ao estatuto de guardião da família como microcosmo da nação e assumir o de guardião da nação como macrocosmo da família. Seu afastamento do vínculo familiar teve como corolário o fenômeno que denomino interdição ao heteroerotismo, na medida em que nesse projeto de nação o romance heteroerótico deveria ser proscrito em benefício da nação.

Nesse espectro, enquanto a mulher-símbolo, metáfora da Irlanda, era priorizada como leitmotiv do sacrifício, a mulher-carne, metonímia da nação, era inscrita, paradoxalmente, como obstáculo e acesso à virtude, na medida em que tentava desviar o homem do compromisso cívico, mas era precisamente o triunfo sobre sua tentação que ratificava a virtude deste último. Nesse ponto, Sean O'Casey diverge do ideário nacionalista ao enfocar os subtraendos do projeto de virilização nacional: a exclusão imposta aos homens inscritos em masculinidades periféricas e, sobretudo, às mulheres. Ora, se na disjunção entre as demandas da mulher como símbolo e da mulher como entidade física apenas os anseios da primeira são considerados, e se tão-somente o homem pode atender ao desejo de uma ou de outra, O’Casey grifa que, ao fazê-lo, este não realiza senão seu próprio desejo. Portanto, o narcisismo masculino, enquanto recusa da castração, satisfaz-se por qualquer via que tome, já que, na definição paradigmática de desejo, não se deseja propriamente o outro, mas ser por ele desejado.

\section{FONTES}

FALLON, Gabriel. Sean O’Casey: The Man I Knew. Boston: Little, Brown, 1965.

GREGORY, Lady Augusta. Our Irish Theatre: A Chapter of Autobiography. New York: G. P. Putnam's Sons, 1913, p. 9.

GREGORY, Lady Augusta. Lady Gregory's Journals. Ed. Lennox Robinson. New York: The Macmillan Company, 1947.

GWYNN, Stephen. The Dublin Play Riots. The Observer, 14 de fevereiro de 1926, p. 16.

HOLLOWAY, Joseph. A Selection from His Unpublished Journal: Impressions of a Dublin Playgoer. Ed. Robert Hogan e Michael J. O’Neill. Carbondale: Southern Illinois University Press, 1967. 
JOYCE, James. James Clarence Mangan. In: The Critical Writings of James Joyce. Ed. Richard Ellmann e Ellsworth Mason. London: Faber and Faber, 1959, p. 175-186.

O’CASEY, Sean. Inishfallen Fare Thee Well. New York: The Macmillan Company, 1949.

O'CASEY, Sean. The Plough and the Stars. In: Three Plays. London: Macmillamn \& Co. LTD, 1964, p. 131-218.

RICHARDS, Sheila. Extract from Sheila Richards' Proposed Autobiography. The Sean O'Casey Review, v. 2, n. 2, p. 175-176, 1976.

SHAW, George Bernard. John Bull's Other Ireland. In: John Bull's Other Ireland and Major Barbara. New York: Brentano's, 1907, p. 1-126.

YEATS, William Butler. Essays and Introductions. New York: Macmillan Company, 1961.

\section{REFERÊNCIAS}

ANDERSON, Benedict. Imagined Communities: Reflections on the Origin and Spread of Nationalism. London: Verso, 1983.

CHATTERJEE, Partha. Whose Imagined Community. In: CHATTERJEE, Partha. The Nation and its Fragments: Colonial and Postcolonial Histories. Princeton: Princeton University Press, 1993, p. 3-13.

COOGAN, Tim Pat. De Valera: Long Fellow, Long Shadow. London: Hutchinson, 1993.

COPJEC, Joan. Imagine there's no woman: Ethics and sublimation. Cambridge: Massachusetts Institute of Technology Press, 2004.

CULLINGFORD, Elizabeth B. Thinking of Her...as...Ireland: Yeats, Pearse and Heaney. Textual Practice, v. 4, n. 1, p. 1-20, 1990.

FREUD, Sigmund. Tipos Psicopáticos no Palco. Edição Standard Brasileira das Obras Psicológicas Completas de Sigmund Freud. v. VII. Rio de Janeiro. Imago, 1969.

FREUD, Sigmund. Atos obsessivos e práticas religiosas. Edição Standard Brasileira das Obras Psicológicas Completas de Sigmund Freud. v. IX. Rio de Janeiro: Imago, 1974.

FREUD, Sigmund. O mal-estar na civilização. Edição Standard Brasileira das Obras Psicológicas Completas de Sigmund Freud. v. XXI. Rio de Janeiro: Imago, 1996.

GRENE, Nicholas. Reality Check: Authenticity from Synge to McDonagh. In: MUTRAN, Munira H.; 
IZARRA, Laura P. Z. (Eds). Irish Studies in Brazil. São Paulo: Humanitas, 2005, p. 69-88.

INNES, Catherine L. The Cambridge Introduction to Postcolonial Literatures in English. Cambridge: Cambridge University Press, 2007.

KIBERD, Declan. Inventing Ireland: The Literature of the Modern Nation. London: Jonathan Cape, 1995.

KILROY, James. The Playboy Riots. Dublin: The Dolmen Press, 1971.

KRAUSE, David. Sean O'Casey: The man and his work. London: Macgibbon \& Kee, 1960.

KRISTEVA, Julia. Powers of Horror: An Essay on Abjection. New York: Columbia University Press, 1982.

MURRAY, Christopher. Twentieth-Century Irish Drama: Mirror Up to Nation. Manchester:

Manchester University Press, 1997, p. 3.

O'RIORDAN, John. O'Casey, the Peerless Ploughman. The O'Casey Review, v. 2, n. 2, p. 177-186, Primavera, 1976.

PAZ, Octavio. El laberinto de la soledad. México, D.F.: Cuadernos Americanos, 1950.

PORTER, Raymond. O'Casey and Pearse. The O'Casey Review, v. 2, n. 2, p. 104-114, Primavera, 1976.

SOMMER, Doris. Foundational Fictions: The National Romances of Latin America. Berkeley, Los Angeles, Oxford: University of California Press, 1991.

WATSON, George. Irish Identity and the Literary Revival: Synge, Yeats, Joyce, and O'Casey. Washington: Catholic University of America Press, 1994. 